\title{
THE METABOLISM IN VITRO OF $\mathrm{C}_{21}$ - AND $\mathrm{C}_{19^{-}}$ STEROIDS BY PREGNANT SHEEP MYOMETRIUM
}

\author{
GADIJA ROSSIER AND G. G. PIERREPOINT \\ Tenovus Institute for Cancer Research, Heath, Cardiff CF4 $4 X X$
}

(Received 12th February 1973)

\begin{abstract}
Summary. The metabolism of $\mathrm{C}_{21}$ - and $\mathrm{C}_{19}$-steroids by sheep myometrium in vitro has been investigated. At 134 days of gestation, extensive

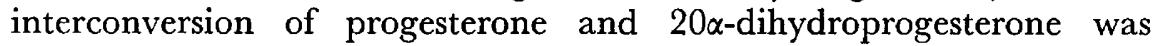
demonstrated, the reaction favouring the reduced form. Low yields only of $20 \beta$-dihydroprogesterone and $17 \alpha$-hydroxyprogesterone were obtained from either precursor. Saturation of the 4-ene bond resulted mainly in the formation of $5 \alpha$-reduced compounds whilst evidence was obtained for the presence of both $3 \alpha$ - and $3 \beta$-hydroxysteroid dehydrogenase activities as opposed to that of a steroid C17-20 lyase.

Similar incubation studies with $\left[4-{ }^{14} \mathrm{C}\right]$ androstenedione and $[1,2-$ $\left.{ }^{3} \mathrm{H}\right]$ epitestosterone at term indicated a low metabolizing ability of the tissue for these steroids. The main metabolites isolated were $5 \alpha$-reduction products whilst no $5 \beta$-reductase activity could be demonstrated. Interconversion of the two substrates was also shown and testosterone bearing both labels was isolated in low yield. There was little evidence that sheep myometrium at this stage of gestation utilizes these $\mathrm{C}_{19}$-steroids as precursors for oestrogen formation.
\end{abstract}

\section{INTRODUGTION}

The control of myometrial activity by the balance of gestagens and oestrogens has received considerable attention over the years (Csapo, 1961a, 1969). The rôle of the placenta in providing these hormones in the higher mammals and allowing ovarian function to wane in the latter stages of pregnancy has recently been reviewed by Ryan (1969), and now provides the phylogenist with considerable data on mammalian adaptation to viviparity.

The suppressive action of the placenta on myometrical activity has been admirably demonstrated by Csapo and his co-workers (Csapo, 1961b; Kuriyama \& Csapo, 1961; Csapo \& Wood, 1968), who showed that the muscular activity was inversely related to the proximity of the placenta. This has been further correlated with myometrial content of progesterone (Runnebaum \& Zander, 1971).

Target organs are not now considered mere recipients of circulating hormones, but can be viewed within the concept of hormone action by their ability to enhance or inactivate the secretions that attend them (Williams-Ashman \& Reddi, 1971). An extension of this concept must include the myometrium and 
it is to this end that the investigations reported here have been directed. The provision by the placenta of steroids to the myometrium has been investigated in the sheep (Pierrepoint, Anderson, Turnbull \& Griffiths, 1973) and a knowledge of their further metabolism is now of prime importance. This communication describes the metabolism in vitro of $\mathrm{C}_{21}$ - and $\mathrm{C}_{19}$-steroids by ovine myometrium taken in the last fifth of gestation.

\section{MATERIALS AND METHODS}

Caesarean hysterectomy was performed on two ewes, at 134 days of gestation and at term, respectively. The myometrium was stripped from the endometrium and finely chopped by hand. The tissue, $4 \mathrm{~g}$ from each uterus, was incubated in $24 \mathrm{ml} \mathrm{Krebs-Ringer} \mathrm{bicarbonate} \mathrm{glucose} \mathrm{medium} \mathrm{(} \mathrm{pH} \mathrm{7.4}$ ), at $39.5^{\circ} \mathrm{C}$ with agitation in an atmosphere of $95 \% \mathrm{O}_{2}$ and $5 \% \mathrm{CO}_{2}$. The incubation flasks contained the following isotopically labelled substrates in equimolar quantities.

Experiment (a) 134-day myometrium

$2 \mu \mathrm{Ci}\left[4-{ }^{14} \mathrm{C}\right]$ progesterone $(56 \mathrm{Ci} / \mathrm{mol})$

$15 \mu \mathrm{Ci}\left[1,2-{ }^{3} \mathrm{H}\right] 20 \alpha$-dihydroprogesterone $(420 \mathrm{Ci} / \mathrm{mol}$ )

Experiment (b) term myometrium

$2 \mu \mathrm{Ci}\left[4-{ }^{14} \mathrm{C}\right]$ androstenedione $(56 \mathrm{Ci} / \mathrm{mol})$

$15 \mu \mathrm{Ci}\left[1,2-{ }^{3} \mathrm{H}\right]$ epitestosterone (17 $\alpha$-hydroxy-4-androst-3one) $(420 \mathrm{Ci} / \mathrm{mol})$

The radioactive substrates were checked for purity in each case by chromatographing on thin layers of silica gel and scanning, using a Berthold Aerograph Model 6000.

After a 2-hr incubation period, the reactions were stopped by the addition of acetone followed by refrigeration at $-15^{\circ} \mathrm{C}$. Non-radioactive carrier steroids were added, $500 \mu \mathrm{g}$ of each in ethanol, to the incubations before extraction, as listed below.

To Incubation (a): Progesterone, 20 $\alpha$-dihydroprogesterone, 20 $\beta$-dihydroprogesterone, $17 \alpha$-hydroxyprogesterone, $5 \alpha$-pregnane-3,20-dione $5 \beta$-pregnane3,20-dione, $3 \beta$-hydroxy-5 $\alpha$-pregnan-20-one, $20 \alpha$-hydroxy-5 $\alpha$-pregnan-3-one, $5 \alpha$ pregnane- $3 \beta, 20 \alpha$-diol, $5 \beta$-pregnane- $3 \alpha, 20 \alpha$-diol, $5 \beta$-pregnane- $3 \beta, 20 \beta$-diol, androstenedione, testosterone, epitestosterone, oestrone.

To Incubation (b): Androstenedione, epitestosterone, testosterone, $5 \alpha$ androstane-3,20-dione, $5 \beta$-androstane-3,20-dione, $5 \alpha$-dihydrotestosterone, $5 \beta$ dihydrotestosterone, $5 \alpha$-dihydroepitestosterone, $5 \beta$-dihydroepitestosterone, androsterone, epiandrosterone, aetiocholanolone, epiaetiocholanolone ( $3 \beta$ hydroxy- $5 \beta$-androstan-17-one), $5 \alpha$-androstane- $3 \alpha, 17 \beta$-diol, oestrone, oestradiol$17 \alpha$, oestradiol- $17 \beta$.

Carrier steroids and their derivatives were isolated and purified on thin layers of Merck silica gel $\mathrm{HF}_{254 / 366}$, unless otherwise stated. The solvent systems employed for the thin-layer chromatography, proportions by volume, were: I Chloroform:acetone (37:3); II Cyclohexane:ethyl acetate (1:1); III Cyclohexane:ethyl acetate (3:1); IV Hexane:ethyl acetate $(3: 2)$; V 
Cyclohexane:ethyl acetate (7:3); VI Benzene:ethyl acetate (9:1); VII Chloroform: ether:acetone:hexane (100:50:1:140); VIII n-Butyl acetate.

Steroids and derivatives were measured on a Pye 104 gas-liquid chromatograph, using 1 or $2 \%$ SE30 on BDH Supasorb mesh (100 to 200) with flame ionization and internal standardization. Standard curves of mass versus peak height ratios of steroids to internal standards were found to be linear. The curves were regressed, using the formula $y=a+b x$, where $a$ and $b$ are the ordinate intercept and slope respectively, and $\mathrm{x}$ and $\mathrm{y}$ are the mass and peak height ratios respectively.

The constants, $a$ and $b$, were determined and the errors associated with the standard curves calculated (Snedecor \& Cochran, 1968). The coefficient of variation of $y$ was found to be $>0$ and $<5$. All analyses were conducted in the region where the coefficient of variation of y was a minimum.

Radioactivity was assessed using a Nuclear Chicago liquid scintillation spectrometer Mark 2. The standard deviation $(\sigma \mathrm{n})$ of estimating the nett counting rate $(n)$ of a sample is given by the equation

$$
\sigma \mathrm{n}^{2}=\frac{\mathrm{s}}{\mathrm{ts}}+\frac{\mathrm{b}}{\mathrm{tb}}
$$

where $s$ and $b$ are the counting rates of gross sample and background respectively $(\mathrm{n}=\mathrm{s}-\mathrm{b})$ and ts and tb are the times taken for counting the two samples respectively.

The coefficient of variation due to counting was calculated and found to lie between values of 0 and $2 \cdot 5$.

\section{RESULTS}

Incubation (a)

Evidence for the identification of steroids isolated and the percentage of radioactivity associated with them are presented in Table 1.

The results show the formation of $59.0 \%{ }^{14} \mathrm{C}$-labelled $20 \alpha$-dihydroprogesterone and $31.5 \%$ tritiated progesterone at the end of the 2-hr incubation period, providing evidence for extensive interconversion of these two substrates by late pregnancy ovine myometrium and that the reaction favours the reduced form. Doubly labelled $20 \beta$-dihydroprogesterone and $17 \alpha$-hydroxyprogesterone were also isolated but in low yield. The formation of $5 \alpha$-reduced compounds from both substrates was of particular interest. The only evidence for $5 \beta$-reduction was the isolation of tritiated $5 \beta$-pregnane- $3 \alpha, 20 \alpha$-diol $(0.76 \%)$. Steroid C17-G20 lyase enzyme activity was not evident from this study.

\section{Incubation (b)}

The results listed in Table 2 demonstrate a low metabolizing ability of ovine myometrium with regard to $\left[4-{ }^{14} \mathrm{C}\right]$ androstenedione and $\left[1,2-{ }^{3} \mathrm{H}\right]$ epitestosterone in that $86 \%$ and $90 \%$, respectively, of these substrates were recovered unchanged. Evidence for the formation of $5 \alpha$-reduced compounds was obtained with the isolation of labelled $5 \alpha$-androstane-3,17-dione, $5 \alpha$ dihydroepitestosterone (17 $\alpha$-hydroxy-5 $\alpha$-androstan-3-one), androsterone and 
epiandrosterone formed mainly from $\left[4-{ }^{14} \mathrm{C}\right]$ androstenedione, although $5 \alpha-$ dihydroepitestosterone was isolated bearing only the tritium label $(1.63 \%)$. There was no evidence of $\mathrm{C}_{19}$-steroid $5 \beta$-reductase activity. The results show some interconversion of the two substrates with the formation of tritiated

Table 1. Steroids isolated and derivatives formed from progesterone and dihydroprogesterone by pregnant sheep myometrium in vitro in Incubation (a)

\begin{tabular}{|c|c|c|c|c|c|}
\hline \multirow{3}{*}{$\begin{array}{l}\begin{array}{c}\text { Steroids isolated and derivatives } \\
\text { formed }\end{array} \\
\text { Progesterone } \\
20 \beta \text {-Dihydroprogesterone } \\
20 \beta \text {-Dihydroprogesterone acetate }\end{array}$} & \multirow{3}{*}{$\frac{\begin{array}{c}\text { Solvent } \\
\text { systems } \\
\text { used }\end{array}}{\mathrm{I} \text { and II* }}$} & \multicolumn{4}{|c|}{ Specific activities } \\
\hline & & \multicolumn{2}{|c|}{$\begin{array}{c}\text { from } \\
{\left[4-{ }^{14} \mathrm{C}\right] \text { progesterone }}\end{array}$} & \multicolumn{2}{|c|}{$\begin{array}{l}\text { from } \\
{\left[1,2-{ }^{3} \text { H }\right] 20 \alpha-d i h y-} \\
\text { droprogesterone }\end{array}$} \\
\hline & & $\begin{array}{l}768 \\
712 \\
769\end{array}$ & {$[35 \cdot 5]$} & $\begin{array}{l}8090 \\
8190 \\
8320\end{array}$ & {$[31 \cdot 5]$} \\
\hline $\begin{array}{l}\text { 20 } \alpha \text {-Dihydroprogesterone } \\
\text { Progesterone } \\
\text { 20 } \beta \text {-Dihydroprogesterone }\end{array}$ & $\begin{array}{l}\mathrm{I} \text { and } \mathrm{II}^{*} \\
\quad \mathrm{I} \\
\mathrm{I}\end{array}$ & $\begin{array}{l}1250 \\
1250 \\
1190\end{array}$ & {$[59 \cdot 0]$} & $\begin{array}{l}10,480 \\
10,570 \\
10,760\end{array}$ & {$[41 \cdot 3]$} \\
\hline $\begin{array}{l}\text { 20 } \beta \text {-Dihydroprogesterone } \\
\text { 20 } \beta \text {-Dihydroprogesterone acetate } \\
\text { Progesterone }\end{array}$ & $\underset{\mathrm{I}}{\mathrm{I} \text { and } \mathrm{II}^{*}}$ & $\begin{array}{l}12 \cdot 8 \\
12 \cdot 8 \\
11 \cdot 1\end{array}$ & {$[0 \cdot 59]$} & $\begin{array}{l}87 \cdot 7 \\
88 \cdot 8 \\
80 \cdot 9\end{array}$ & {$[0 \cdot 33]$} \\
\hline $\begin{array}{l}\text { 17 } \alpha \text {-Hydroxyprogesterone } \\
17 \alpha, 20 \beta \text {-dihydroxy-4-pregnen-3-one } \\
17 \alpha \text {-Hydroxy,20 } \beta \text {-acetoxy-4- } \\
\text { pregnen-3-one }\end{array}$ & $\begin{array}{c}\text { I and II* } \\
\text { I } \\
I\end{array}$ & $\begin{array}{r}\overline{0} \cdot 4 \\
0 \cdot 4\end{array}$ & {$[0 \cdot 02]$} & $\begin{array}{l}7 \cdot 2 \\
6 \cdot 4 \\
6 \cdot 6\end{array}$ & {$[0.43]$} \\
\hline $\begin{array}{l}\text { 5 } \alpha \text {-Pregnane-3,20-dione } \\
5 \alpha \text {-Pregnane-3 } \beta, 20 \beta \text {-diol } \\
5 \alpha \text {-Pregnane- } 3 \beta, 20 \beta \text {-diol diacetate }\end{array}$ & $\begin{array}{l}\text { I and VI } \\
\text { I } \\
\text { VI }\end{array}$ & $\begin{array}{l}9 \cdot 70 \\
8 \cdot 96 \\
8 \cdot 76\end{array}$ & {$[0 \cdot 89]$} & $\begin{array}{l}59 \cdot 1 \\
52 \cdot 3 \\
54 \cdot 9\end{array}$ & {$[0 \cdot 43]$} \\
\hline 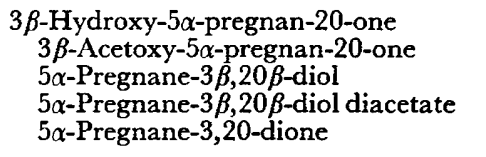 & $\begin{array}{l}\text { I and IV } \\
\text { III } \\
\text { I } \\
\text { VI } \\
\text { VI }\end{array}$ & $\begin{array}{l}57 \cdot 9 \\
56 \cdot 9 \\
56 \cdot 5 \\
- \\
-\end{array}$ & {$[2 \cdot 72]$} & $\frac{659}{\overline{-}}$ & {$[2 \cdot 49]$} \\
\hline 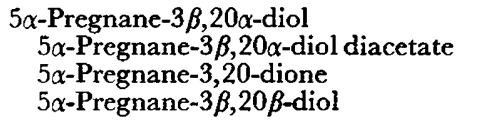 & $\begin{array}{l}\text { I and II* } \\
\text { II* } \text { and } V I_{\text {VI }} \\
\text { I }\end{array}$ & $\begin{array}{l}\overline{33 \cdot 2} \\
30 \cdot 3 \\
34 \cdot 4\end{array}$ & {$[1 \cdot 71]$} & $\begin{array}{l}\overleftarrow{401} \\
433 \\
412\end{array}$ & {$[1 \cdot 66]$} \\
\hline $\begin{array}{l}5 \beta \text {-Pregnane- } 3 \alpha, 20 \alpha \text {-diol } \\
5 \beta \text {-Pregnane-3,20-dione } \\
5 \beta \text {-Pregnane- } 3 \beta, 20 \beta \text {-diol }\end{array}$ & $\underset{\text { II }}{\mathrm{II}^{*} \text { and I }}$ & $\begin{array}{l}0 \\
0 \\
0\end{array}$ & {$[0]$} & $\begin{array}{l}194 \\
207 \\
190\end{array}$ & {$[0 \cdot 76]$} \\
\hline
\end{tabular}

The derivatives formed in each case and the solvent systems employed in their purification are listed. The specific activities are expressed in terms of $\mathrm{d} / \mathrm{min} / \mathrm{nmol}$ (estimated coefficient of variation is $>0$ and $<8 \%$ whilst the percentage of initial radioactivity associated with each steroid is given in parentheses.

Other steroids investigated but found not to be radioactive: $20 \beta$-hydroxy-5 $\alpha$-pregnan-3-one; $5 \beta$ -

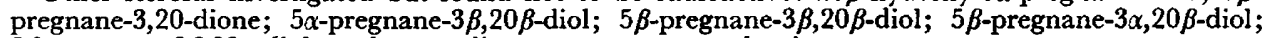
$5 \beta$-pregnane- $3 \beta, 20 \alpha$-diol; androstenedione; testosterone and epitestosterone.

* Run on Merck Alumina PF $_{254 / 366}$ Type T.

androstenedione $(1.45 \%)$ and ${ }^{14} \mathrm{C}$-labelled epitestosterone $(1.34 \%)$. Testosterone was isolated bearing both labels in low yield. There was little evidence for aromatization of these $\mathrm{C}_{19}$-steroid substrates by this tissue at this stage of gestation. 


$$
C_{21} \text { - and } C_{19} \text {-steroid metabolism by sheep myometrium }
$$

Table 2. Steroids isolated and derivatives formed from androstenedione and epitestosterone by pregnant sheep myometrium in vitro in Incubation (b)

\begin{tabular}{|c|c|c|c|c|c|}
\hline \multirow{2}{*}{$\begin{array}{l}\text { Steroids isolated and derivatives } \\
\text { formed }\end{array}$} & \multirow{2}{*}{$\begin{array}{l}\text { Solvent } \\
\text { systems } \\
\text { used }\end{array}$} & \multicolumn{4}{|c|}{ Specific activities } \\
\hline & & \multicolumn{2}{|c|}{$\begin{array}{l}\text { from } \\
{\left[4-{ }^{14} C\right] \text { andros- }} \\
\text { tenedione }\end{array}$} & \multicolumn{2}{|c|}{$\begin{array}{c}\text { from } \\
{\left[1,2-{ }^{3} H\right] \text { epi- }} \\
\text { testosterone }\end{array}$} \\
\hline $\begin{array}{l}\text { Androstenedione } \\
\text { Testosterone } \\
\text { Testosterone acetate }\end{array}$ & $\begin{array}{l}\text { I and II } \\
\text { III }\end{array}$ & $\begin{array}{l}2203 \\
2277 \\
2141\end{array}$ & {$[86 \cdot 0]$} & $\begin{array}{l}265 \\
256 \\
249\end{array}$ & {$[1 \cdot 45]$} \\
\hline $\begin{array}{l}\text { Epitestosterone } \\
\text { Androstenedione } \\
\text { Epitestosterone acetate }\end{array}$ & $\underset{\substack{\text { I, IV and II } \\
\text { III }}}{*}$ & $\begin{array}{l}32 \cdot 2 \\
35 \cdot 8 \\
35 \cdot 5\end{array}$ & {$[1 \cdot 34]$} & $\begin{array}{l}15,890 \\
16,140 \\
15,670\end{array}$ & {$[90 \cdot 2]$} \\
\hline $\begin{array}{l}\text { Testosterone } \\
\text { Androstenedione } \\
\text { Testosterone acetate }\end{array}$ & $\mid \begin{array}{c}\text { I, IV and II* } \\
\text { III } \\
\text { III }\end{array}$ & $\begin{array}{l}55 \cdot 9 \\
48 \cdot 8 \\
52 \cdot 3\end{array}$ & {$[2 \cdot 03]$} & $\begin{array}{l}45 \cdot 5 \\
44 \cdot 5 \\
44 \cdot 8\end{array}$ & {$[0 \cdot 26]$} \\
\hline 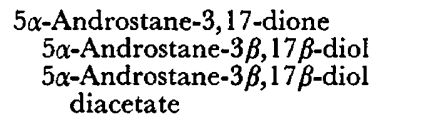 & $\begin{array}{l}\text { VI } \\
\text { I } \\
\text { III }\end{array}$ & $\begin{array}{l}16 \cdot 5 \\
15 \cdot 4 \\
16 \cdot 2\end{array}$ & {$[0 \cdot 62]$} & $\begin{array}{l}0 \\
0 \\
0\end{array}$ & {$[0]$} \\
\hline 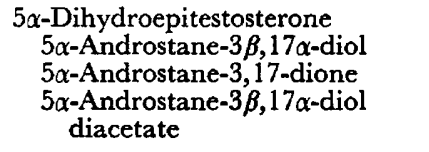 & $\begin{array}{l}\text { I } \\
\text { II* } \\
\text { VI } \\
\text { III }\end{array}$ & $\begin{array}{c}-\overline{0} \\
0 \\
0\end{array}$ & [0] & $\begin{array}{l}\overrightarrow{265} \\
306 \\
297\end{array}$ & {$[1 \cdot 63]$} \\
\hline $\begin{array}{l}\text { Androsterone } \\
\text { Androsterone acetate } \\
5 \alpha \text {-Androstane-3,17-dione }\end{array}$ & $\begin{array}{l}\text { I } \\
\text { VII } \\
\text { VI }\end{array}$ & $\begin{array}{l}22 \cdot 4 \\
22 \cdot 0 \\
22 \cdot 3\end{array}$ & {$[0 \cdot 87]$} & $\begin{array}{l}4 \cdot 5 \\
3 \cdot 9 \\
4 \cdot 5\end{array}$ & {$[0 \cdot 02]$} \\
\hline $\begin{array}{l}\text { Epiandrosterone } \\
5 \alpha \text {-Androstane-3,17-dione } \\
5 \alpha \text {-Androstane-3 } \beta, 17 \beta \text {-diol } \\
\text { diacetate }\end{array}$ & $\begin{array}{l}\text { I } \\
\text { VI } \\
\text { III }\end{array}$ & $\begin{array}{l}6 \cdot 2 \\
5 \cdot 6 \\
6 \cdot 2\end{array}$ & {$[0 \cdot 23]$} & $\begin{array}{l}0 \\
0 \\
0\end{array}$ & {$[0]$} \\
\hline $\begin{array}{l}\text { Oestrone } \\
\text { Oestrone acetate } \\
\text { Oestrone 3-methyl ether }\end{array}$ & I, IIII IV & $\begin{array}{l}0.6 \\
0.5\end{array}$ & [? Trace] & 0 & {$[0]$} \\
\hline
\end{tabular}

The derivatives formed in each case and the solvent systems employed in their purification are listed. The specific activities are expressed in terms of $\mathrm{d} / \mathrm{min} / \mathrm{nmol}$ (estimated coefficient of variation is $>0$ and $<8 \%$ ) whilst the percentage of initial radioactivity associated with each steroid is given in parentheses.

Other steroids investigated but found not to be radioactive: $5 \beta$-androstane-3,17-dione; $5 \alpha$-dihydrotestosterone; $5 \beta$-dihydrotestosterone; $5 \beta$-dihydroepitestosterone; aetiocholanolone; $3 \beta$-hydroxy- $5 \beta$ androstan-17-one; oestradiol-17 $\beta$; oestradiol-17 $\alpha$.

* Run on Merck Alumina $\mathrm{PF}_{254 / 366}$ Type T.

\section{DISGUSSION}

It is well documented that progesterone is implicated in several aspects of gestation such as implantation, control of myometrial activity and the onset of parturition and lactation (Csapo, 1961a; Deanesly, 1966; Kuhn \& Briley, 1970).

An insight into the mechanism of action of progesterone may be achieved by studying its metabolism in target organs correlated with the ability of the target cell to bind it or its metabolites. The conversion, for example, of progesterone to its $20 \alpha$-reduced derivative has been investigated in the rat where 
the progesterone 'withdrawal' theory in initiating parturition seems to hold true. The formation of the reduced compound is considered as a possible regulatory mechanism of progesterone concentration during the various stages of gestation (Kuhn \& Briley, 1970). These authors suggest that this reaction allows for the removal of progesterone and, by competition of the product for enzyme sites, lessens the further formation of the parent steroid. The reduced form itself seems to have no direct effect on the length of gestation, the onset of parturition or lactation (Wiest, 1968; Madhwa Raj \& Moudgal, 1970).

The results of the present in-vitro investigation show that extensive inter-

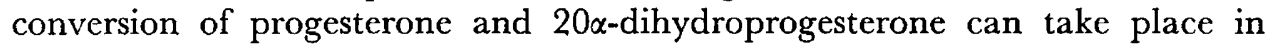
ovine myometrium and that the equilibrium favours the reduced form. A-ring reduction results mainly in the formation of compounds of the $5 \alpha$-series. The pregnant sheep myometrium shows therefore some similarity with that of man (Bryson \& Sweat, 1969) and rat (Wichmann, 1967). A distinguishing feature from human myometrium was the presence of both $3 \alpha$ - and $3 \beta$-hydroxysteroid dehydrogenase activities, the latter predominating. This contrasts too with the rat myometrium in which only the $3 \alpha$-hydroxysteroid dehydrogenase has been demonstrated (Wiest, 1963; Wichmann, 1967).

It is characteristic of the myometrial metabolism of progesterone in the species so far studied that the major metabolites are $20 \alpha$-dihydroprogesterone and $5 \alpha$-saturated $\mathrm{C}_{21}$-steroids. The uptake and binding of $5 \alpha$-pregnanedione by cell nuclei from the rat uterus has been demonstrated (Armstrong \& King, 1970 ), as well as an increase in nuclear $5 \alpha$-reductase activity under conditions of enhanced biological activity of progesterone. In the uterine cytosol of the guinea-pig, there seems to be a specific intracellular binding protein for progesterone which will also bind, and is competed for, by $5 \alpha$-pregnanedione but not by $20 \alpha$-dihydroprogesterone (Milgrom \& Baulieu, 1970).

The investigation of $\mathrm{C}_{19}$-steroid metabolism in the myometrium of the pregnant sheep has demonstrated the interconversion of androstenedione and epitestosterone in this tissue. This reaction has previously been shown to occur in sheep placental tissue (Pierrepoint, Anderson, Griffiths \& Turnbull, 1970), and whole blood (Lindner, 1961). Furthermore, it is found that, after the short-term perfusion of the sheep placenta in situ with $\left[7 \alpha^{3} \mathrm{H}\right]$ androstenedione, labelled epitestosterone represented quantitatively the major steroid metabolite subsequently isolated from the myometrium. Following a similar perfusion with $\left[4-{ }^{14} \mathrm{C}\right]$ androstenedione and $\left[7 \alpha-{ }^{3} \mathrm{H}\right]$ dehydroepiandrosterone, double-labelled epitestosterone was again isolated from this organ (G. Rossier and G. G. Pierrepoint, unpublished observation).

The finding that epitestosterone is aromatized to oestradiol-17 $\alpha$ in ovine placental tissue (Pierrepoint et al., 1970) was considered to be of possible significance in relation to myometrial function. Our studies on oestrogen metabolism in ovine myometrium, however, have shown oestradiol-17 $\beta$ to be the predominant epimer formed by this target tissue (Rossier \& Pierrepoint, 1974). It is possible, therefore, that the aromatization of epitestosterone to oestradiol-17 $\alpha$ is an inactivating mechanism, particularly in view of the fact that large quantities of this oestrogen are excreted in the urine of the pregnant 
sheep (Fèvre \& Rombauts, 1966). Epitestosterone appears to have little androgenic activity (Dorfman \& Shipley, 1956) and its formation could be a mechanism regulating circulating levels of potent androgens, thus protecting the mother from the possible virilizing effects of the fetus. It remains to be determined whether it has any biological activity with regard to myometrial contractility in this species, especially in the light of its ability to induce parturition when infused at a rate of $1 \mathrm{mg} / 24 \mathrm{hr}$ into the sheep fetus (Pierrepoint et al., 1970, 1973).

It is pertinent to note, however, that the $17 \beta$-hydroxysteroid dehydrogenase with respect to androstenedione is more active than the equivalent $17 \alpha$ orientated enzyme, $\mathrm{cf}$. the greater conversion of oestrone to oestradiol-17 $\beta$ in preference to the 17 $\alpha$-epimer (Rossier \& Pierrepoint, 1974). The formation and action of testosterone in this organ requires further investigation with reference to the purported progestational effects of certain androgens (Emmens, 1969).

Earlier work in this laboratory has shown that androstenedione is metabolized in vitro by sheep fetal liver with the formation of $5 \beta$-reduction products (Anderson, Pierrepoint, Griffiths \& Turnbull, 1970). By contrast, the results of the present investigation show the prevalence of $\mathrm{C}_{19}$-steroid- $5 \alpha$-reductase activity in ovine myometrium in the last half of gestation. It is obviously essential to extend these studies to investigate the function of such reduced products in a target organ that would appear to be intimately involved in the control of its own particular hormonal milieu.

\section{AGKNOWLEDGMENTS}

The authors wish to thank the Wellcome Trust and the Tenovus Organization for their generous financial support. The helpful advice of Professor K. Griffiths and the surgical assistance of $\operatorname{Dr} \mathrm{A}$. B. M. Anderson and Mr J. Wilson are gratefully acknowledged.

\section{REFERENCES}

Anderson, A. B. M., Pierrepoint, G. G., Griffiths, K. \& Turnbull, A. G. (1970) Steroid metabolism in vitro by foetal sheep liver. $\mathcal{F}$. Endocr. $48,665$.

Armstrong, D. T. \& King, E. R. (1970) Conversion of progesterone to $5 \alpha$-pregnan-3,20-dione ( $5 \alpha-P)$ by uterine nuclei, and its possible significance. Fedn Proc. Fedn Am. Socs exp. Biol. 29, 250.

BRYSON, M. J. \& SwEAT, M. L. (1969) Metabolism of progesterone in human myometrium. Endocrino$\log y, \mathbf{8 4}, 1071$.

Cs^PO, A. (1961 a) The in vivo and in vitro effects of oestrogen and progesterone on the myometrium. In: Mechanism of Action of Steroid Hormones, p. 126. Eds. G. A. Villee and L. L. Engel. Pergamon Press, Oxford.

Csapo, A. (1961b) Defence mechanism of pregnancy. In: Progesterone and the Defence Mechanism of Pregnancy. Ciba Foundation Study Group No. 9, pp. 3-31. Eds. G. E. W. Wolstenholme and M. P. Cameron. Churchill, London

Csapo, A. (1969) The four direct regulatory factors of myometrial function. In: Progesterone: its Regulatory Effect on the Myometrium. Ciba Foundation Study Group No. 34, pp. 13-55. Eds. G. E. W. Wolstenholme and J. Knight. Churchill, London.

Csapo, A. I. \& Woon, C. (1968) The endocrine control of the initiation of labour in the human. In: Recent Advances in Endocrinology, p. 207. Ed. V. H. T. James. Little, Brown \& Co., Boston.

Deanesly, R. (1966) The endocrinology of pregnancy and foetal life. In: Marshall's Physiology of Reproduction, p. 891. Ed. A. S. Parkes. Longmans Green, London.

Dorfman, R. I. \& Shipley, R. A. (1956) Androgens, biochemistry, physiology and clinical significance, p. 590. John Wiley \& Sons Inc., New York.

Emmens, C. W. (1969) Physiology of gonadal hormones and related synthetic compounds. In: Reproduction in 
Domestic Anmials, p. 92. Eds. H. H. Cole and P. T. Cupps, 2nd edn. Academic Press, New York.

Fèvre, J. \& Rombaưs, P. (1966) Étude de l'excrétion urinaire des oestrogenès chez la brebis pendant la gestation. Annls Biol. anim. Biochim. Biophys. 6, 165.

KunN, N. J. \& BRILEY, M. S. (1970) The roles of pregn-5-ene-3 $\beta, 20 \alpha$-diol and 20 $\alpha$-hydroxysteroid dehydrogenase in the control of progesterone synthesis preceding parturition and lactogenesis in the rat. Biochem. $\mathbf{J} .117,193$.

Kuriyama, H. \& Gsapo, A. I. (1961) Placenta and myometrial block. Am. F. Obstet. Gynec. 82, 592.

LiNDNER, H. R. (1961) Androgen and related compounds in the spermatic vein blood of domestic animals. II. Species-linked differences in the metabolism of androstenedione in blood. $\mathcal{F}$. Endocr. 23,161 .

Madhwa Raj, H. G. \& Moudgal, N. R. (1970) Hormonal control of gestation in the intact rat. Endocrinology, 86, 874.

Mrlgrom, E. \& Bauliev, E. E. (1970) Progesterone in uterus and plasma. IV. Progesterone receptor(s) in guinea pig uterus cytosol. Steroids, 16,741 .

Pierrepoint, C. G., Anderson, A. B. M., Griffiths, K. \& Turnbule, A. C. (1970) Investigations into the metabolism in vitro of $\mathrm{C}_{19}$-steroids by the sheep placenta. Biochem. F. 118, 901 .

Pierrepoint, G. G., Anderson, A. B. M., Turnbull, A. G. \& Griffiths, K. (1973) In vivo and in vitro studies of steroid metabolism in the sheep placenta. In: The Endocrinology of Pregnancy and Parturition: Experimental Studies in the Sheep, p. 40. Ed. C. G. Pierrepoint. Alpha Omega Alpha Publishing Company, Cardiff.

Rossier, G. \& Pierrepoint, G. G. (1974) Oestrogen metabolism in sheep myometrium. J. Reprod. Fert. 37 (in press).

Runnebaum, B. \& Zander, J. (1971) Progesterone and 20 $\alpha$-dihydroprogesterone in human myometrium during pregnancy. Acta endocr., Copenh. Suppl. 150.

RYAN, K. J. (1969) Theoretical basis for endocrine control of gestation-a comparative approach. In: The Foeto-Placental Unit, p. 120. Excerpta med. Int. Congr. Ser. No. 183.

SNEdecor, G. W. \& Cochran, W. G. (1968) Statistical methods, 6th edn, p. 135. Iowa University Press, Ames, Iowa.

WichmanN, K. (1967) On the metabolism and subcellular distribution of progesterone in the myometrium of the pregnant rat. Acta endocr., Copenh. Suppl. 116.

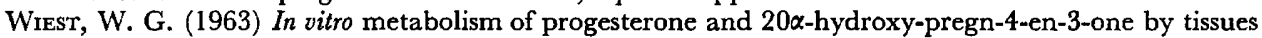
of the female rat. Endocrinology, 73, 310.

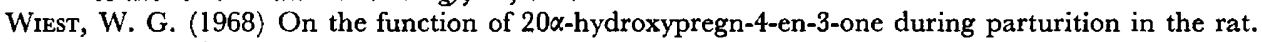
Endocrinology, 83, 1181.

Williams-Ashman, H. G. \& Reddi, A. H. (1971) Actions of vertebrate sex hormones. A. Rev. Physiol. 33,31 . 